\title{
Psychosocial Models of Gender Development
}

\author{
Firdos Jehan $^{1}$, Mustafa Nadeem Kirmani ${ }^{2}$
}

\section{ABSTRACT}

Thebehavioral and psychological differences between women and men have puzzled social scientists for many years. Differences between men and women are often overestimated and their behavioral, cognitive and emotional differences are often attributed to innate biological factors. Stereotyped beliefs about men and women often have serious social and clinical implications. Research in gender psychology has shown that men and women are more similar than different. Besides biological models, psychologists have given many models which helps describe and explain the various psychosocial theories of gender development. This paper will attempt to distinguish between two often confusing terms sex and gender and highlights various psychosocial models of gender development leading to possible gender differences in terms of cognitions, emotions and behaviors.

Keywords: Gender, sex, gender development

Sex refers to the biological categories of male and female, categories distinguished by genes, chromosomes, and hormones. Culture has no influence on one's sex. Sex is a relatively stable category that is not easily changed, although recent technology has allowed people to change their biological sex. Gender, by contrast, is a much more fluid category of male and female. These categories are distinguished from one another by a set of psychological features and role attributes that society has assigned to the biological category of sex.

Unger (1990) defines gender as "the cognitive and perceptual mechanisms by which biological differentiation is translated into social differentiation". A feature of the male sex category includes the $\mathrm{Y}$ chromosome; regardless of whether a male wears a baseball cap or barrettes, is competitive or empathetic, he is of the male sex because he possesses the $\mathrm{Y}$ chromosome. Personality and appearance are related to the gender category.The first period focused on the differences between men and women and was marked by the publication of a book by Ellis (1894) titled Man and Woman which called for a scientific approach to the study of the similarities and differences between men and women.

\footnotetext{
${ }^{1}$ Rehabilitation Psychologist, Jubilant Psyche Solutions, Aligarh

${ }^{2}$ Research Scholar,Department of Pychology, Aligarh Muslim University, Aligarh
} 
In the past two decades, research on sex and gender has proliferated. There have been two recent trends. The first has been to view gender as a multifaceted or multidimensional construct, meaning that the two dimensional view of masculinity and femininity is not sufficient to capture. The development of the unmitigated agency and unmitigated communion scales was a first step in this direction. The second research direction has been to emphasize the social context in which gender occurs. The research on gendrdiagnosticity addresses this issue. Emphasis on the social context led to research on gender- role constraints, the difficulties people face sue to the limits a society places on gender- role appropriate behavior.

Biological theories of sex differences identify genes and hormones, as well as the structure and function of the brain, as the causes of observed differences in physical appearance, cognition, behavior, and even gender roles.

\section{PSYCHOLOGICAL MODELS OF GENDER DEVELOPMENT}

It is important to understand the various psychological theories of gender development. These theories help us understand the origin of possible gender differences. The implication of these theories lies in knowing the possible gender differences in various aspects of behaviors in men and women.

\section{Social Learning Model}

According to social learning model, learning is produced by observation rather than by directly experiencing reinforcement or punishment (Mischel. 1993). Observation provides many opportunities for learning, including the learning of gender-related behaviors among children. The social environment provides children with examples of male and female models who perform different behaviors, including gender-related ones. The models who influence children include mothers and fathers, but also many others, both real people and media images of boys, girls, men, women, and cartoon characters. In observing these many male and female models, children have abundant opportunities to learn. However, not all models have the same influence for all children, and not all behaviors are equally likely to be imitated.

The differential influence of models relates to their power or prestige as well as to the observer's attention and perception of the similarity between model and observer. Children tend to be more influenced by powerful models than by models with less power (Bussey\& Bandura, I984), but children are also more influenced by models who are similar to them. This similarity extends lo gender, with children more likely to imitate same-sex models than other-sex models. Another important factor in performing a learned behavior is observing the consequences of that behavior. If people observe a behavior being rewarded, then they are more likely to perform that behavior than if they see the same behavior punished or unrewarded. Social learning theorists believe that reinforcement and punishment are not essential for learning, which occurs through observation. Instead, reinforcement and punishment are more important to performance, affecting the likelihood that a learned behavior will be performed in circumstances similar to those observed. 


\section{Psychosocial Models of Gender Development}

Children develop in an atmosphere in which they are exposed to models of genderstereotypic behaviors "in the home, in schools, on playgrounds, in readers and storybooks, and in representations of society on the television screens of every household" (Bandura, 1986). These presentations do two things. First, all children are exposed to both female and male models, so all children learn the gender-related behaviors associated with bothgenders. Second, children learn which behaviors are gender-appropriate for them. Children learn that certain behaviors arc rewarded for girls but not for boys; for other behaviors, the rewards come to boys and not to girls.

Children experience many sources of modeling and reinforcement, and these sources influence the development of gender-related behaviors (Beal, 1994). When their children are infants, parents interact differently with their sons and daughters. For example, children accept and show equal enthusiasm for toys typically considered girls' and boys' toys (Idle, Wood, \& Desmarais. 1993), but parents use some gender-typical preferences in selecting activities and toys for their children. Studies that observe parental interactions with children have confirmed gender differences in treatment.

Social learning theory hypothesizes that these forces affect gender-related thinking, and children come to develop gender knowledge and gender standards for their own behavior. In children age 2 to 4 years, behavior typical of the same sex was more common than behavior typical of the other sex for all ages of children (Bussey\& Bandura, 1984). The younger children in the study reacted to their peers in gender-stereotypical ways but did not regulate their own behavior by these same standards, whereas the older children did both. These results indicate that these 4-year-olds had begun to develop a coherent set of cognitive strategies for controlling their gender-related behaviors.

Sandra Bem (1985) criticized social learning theory, arguing that the theory portrays children as too passive. Bern pointed out that children's behavior shows signs of more active involvement than social learning theory hypothesize. Children do not exhibit a gradual increase in gender-related behaviors, hut rather seem to form cognitive categories for gender and then acquire gender-related knowledge around these categories. In addition, research evidence suggests that children may develop stronger gender stereotypes than their parents convey, which implies that children actively organize information about gender. Other social theories of gender development place a stronger emphasis on cognitive organization than doe's social learning theory.

\section{Cognitive Developmental Model}

The cognitive developmental model was propounded by Piaget. He was inspired by the work of Lawrence Kohlberg (1966) on moral development of children. He attempted to understand children's moral development through children's cognitions. Cognitive developmental theory views the acquisition of gender-related behaviors as part of children's general cognitive development. This development occurs as children mature and interact with the 


\section{Psychosocial Models of Gender Development}

world, forming an increasingly complex and accurate understanding of their bodies and the world.

Cognitive developmental theorists see the development of gender-related behaviors as pan of the task of cognitive development. Very young children, lacking a concept of self, can have no concept of their gender. Most 2'/2-year-olds are unable to consistently apply the words boy or girl to self or others; thus they fail at gender labeling. Kohlberg (1966) hypothesized that children acquire some preliminary category information about gender during early childhood, but gender constancy, the belief that their genders will remain the same throughout life, is a cognitively more complex concept that may not appear until between ages 4 and 7 years.

Cognitive developmental theory views the acquisition of gender-related behaviors as a by-product of the cognitive development of gender identity. Children begin to adopt and exhibit gender-related behaviors because they adopt a gender identity and strive to be consistent with this identity. On the other hand, social learning theory hypothesizes that children come to have a gender identity because they model gender-related behaviors. Through the performance of these behaviors, children conform to either the masculine or feminine social roles of their culture. In summary, social learning theory sees gender identity as coming from performance of genderrelated behaviors, whereas cognitive developmental theory sees gender-related behaviors as coming from the cognitive adoption of a gender identity.

\section{Gender Schema Model}

Gender schema model is an extension of the cognitive developmental theory. A schema is "a cognitive structure, a network of associations that organizes and guides an individual's perceptions" Piaget used the term schema (plural, schemata or schemas to describe how cognitions are internalized around various topics; gender schema theory hypothesizes that children develop gender-related behaviors because they develop schemata that guide them to adopt such behaviors. In this view, gender-related behaviors appear not only as a result of general cognitive development, but also because children develop special schemata related to gender.

According to gender schema theory, the culture also plays a role in gender development, providing the reference for the formation of gender schemata. Not only are children ready to encode and organize information about gender, but they do so in a social environment that defines maleness and femaleness (Bem, 1985). As children develop, they acquire schemata that guide their cognitions related to gender. These schemata influence information processing and problem solving in memory and also regulate behavior (Martin \&Halverson, 1981). Gender schema theorists posit that children use these schemata to develop a concept of self versus others, and each child's gender schema is included in that child's self-schema, or self-concept. In addition, gender schemata can provide a guide for concepts of personal masculinity and femininity, including personal judgments about how people personally fit, or fail to fit, these 
schemata. Thus, gender schema theory provides an explanation for the concepts of masculinity and femininity and how people apply these concepts to themselves.

Bem (1985)emphasized the process rather than the content of gender schemata. The information in (he schemata is not as important as the process of forming schemata and acting in ways that are consistent with them. Gender schema theory predicts that that cognitive change that accompany schema formation lead to the ways that children process gender-related information, which changes the ways in which they behave.

Gender schema theory also predicts that developing gender schemata increases accuracy and memory for gender consistent information compared to gender-inconsistent information. A number of studies have demonstrated such memory effects in both children and adults. Gender typed college students tended to remember words in clusters related to gender. For example, the women's proper nouns in a cluster and the men's names in another. This schematicity did not effect the number of words remembered, but the organization of memory differed according to participants' gender schemata. In addition, participants with strong gender schemata were faster at making gender-related judgments that were consistent with their gender schmeta than they were at making judgements inconsistent with their schemata.

In summary, gender schema theory extends the cognitive developmental theory by hypothesizing the existence of gender schemata, cognitive structures that internally represent gender-related information and guide perception and behavior. Children internalize their schemata for masculinity or femininity to form a self-concept, or self-schema, for gender-related behaviors. Research has indicated that gender schemata can affect the processing of genderrelated information and can lead to gender stereotyping. Parents can attempt to circumvent gender-related messages by concentrating on the biological rather than the social correlates of gender, but all children come to understand their culture's messages about gender.

\section{GENDER SCRIPT THEORY}

Gender script model is an extension of gender schema theory, proposing that the social knowledge that children acquire concerning gender is organized in sequential form. Schemata are representations of knowledge, whereas scripts depict an organized sequence of events.

Applied to gender role acquisition, gender scripts are "temporally organized event sequences. But in addition, gender scripts possess a gender role stereotype component which defines which sex stereotypically performs a given sequence of events" (Levy \&Fivush, 1993). For scripts such as eating lunch, the gender of the actor is not important, but the script for cooking lunch is likely to be gender specific.

Therefore, the sequencing component of gender script theory seems to broaden the concept of gender schemata. The research on gender script theory is less complete than the other 
theories of gender role development, but this theory is a promising addition to the other social theories of gender development.

\section{CONCLUSION}

The development of gender identity and sex typed behavior is influenced by a complex network of biological, psychological and sociocultural factors. Since none of these model alone will not explain gender differences, various models of gender development have been proposed by a group psychologists to understand this interesting area of behavioral sciences. Gender is a complex issue, so other models of gender development need to be formulated based on inclusive approach.

Table 1: A Comparison of Psychosocial Theories of Gender Development

\begin{tabular}{|c|c|c|c|c|}
\hline $\begin{array}{l}\text { Course of } \\
\text { Development }\end{array}$ & $\begin{array}{l}\text { Social Learning } \\
\text { Theory }\end{array}$ & $\begin{array}{l}\text { Cognitive } \\
\text { Development } \\
\text { Theory }\end{array}$ & $\begin{array}{l}\text { Gender } \\
\text { Schema Theory }\end{array}$ & $\begin{array}{l}\text { Gender Script } \\
\text { Theory }\end{array}$ \\
\hline $\begin{array}{ll}\text { Sources } & \text { of } \\
\text { Gender } & \\
\text { Differences } & \end{array}$ & $\begin{array}{l}\text { Reinforcement } \\
\& \text { observation of } \\
\text { models }\end{array}$ & $\begin{array}{l}\text { General } \\
\text { cognitive } \\
\text { development } \\
\text { especially } \\
\text { gender } \\
\text { constancy }\end{array}$ & $\begin{array}{l}\text { Development of } \\
\text { gender specific } \\
\text { schemata }\end{array}$ & $\begin{array}{l}\text { Learning gender } \\
\text { scripts }\end{array}$ \\
\hline $\begin{array}{l}\text { Children } \\
\text { participation } \\
\text { involves..... }\end{array}$ & $\begin{array}{l}\text { Choosing which } \\
\text { model to imitate }\end{array}$ & $\begin{array}{l}\text { Organizing } \\
\text { information } \\
\text { about the } \\
\text { physical world }\end{array}$ & $\begin{array}{l}\text { Developing } \\
\text { schemata } \\
\text { specific } \\
\text { gender }\end{array}$ & $\begin{array}{l}\text { Developing } \\
\text { scripts through } \\
\text { social } \\
\text { interaction }\end{array}$ \\
\hline $\begin{array}{l}\text { Beginning of } \\
\text { Gender } \\
\text { Development }\end{array}$ & $\begin{array}{l}\text { Usually during } \\
\text { infancy }\end{array}$ & $\begin{array}{l}\text { During } \\
\text { preschool years }\end{array}$ & $\begin{array}{l}\text { During } \\
\text { preschool years }\end{array}$ & $\begin{array}{l}\text { During early } \\
\text { preschool years }\end{array}$ \\
\hline $\begin{array}{l}\text { Gender } \\
\text { development } \\
\text { proceeds...... }\end{array}$ & $\begin{array}{l}\text { Gradually, } \\
\text { becoming more } \\
\text { like adult } \\
\text { knowledge }\end{array}$ & $\begin{array}{l}\text { Through a series } \\
\text { of stages }\end{array}$ & $\begin{array}{l}\text { Through } \\
\text { development of } \\
\text { schemata }\end{array}$ & $\begin{array}{l}\text { Through } \\
\text { learning script } \\
\text { components }\end{array}$ \\
\hline $\begin{array}{l}\text { Gender } \\
\text { development } \\
\text { finishes...... }\end{array}$ & $\begin{array}{l}\text { During } \\
\text { adulthood if at } \\
\text { all }\end{array}$ & $\begin{array}{lr}\text { During } & \text { late } \\
\text { childhood } & \text { or } \\
\text { adolescents } & \\
\end{array}$ & $\begin{array}{l}\text { During late } \\
\text { childhood }\end{array}$ & $\begin{array}{l}\text { When scripts are } \\
\text { learned }\end{array}$ \\
\hline $\begin{array}{l}\text { Girls } \\
\text { boys..... }\end{array}$ & $\begin{array}{l}\text { Develop gender } \\
\text { knowledge as } \\
\text { different gender } \\
\text { related } \\
\text { behaviors }\end{array}$ & $\begin{array}{l}\text { Develop similar } \\
\text { cognitive } \\
\text { understanding of } \\
\text { gender }\end{array}$ & $\begin{array}{l}\text { Develop } \\
\text { different } \\
\text { structures and } \\
\text { schemata } \\
\text { depending on } \\
\text { parents and } \\
\text { family patterns }\end{array}$ & $\begin{array}{l}\text { Develop } \\
\text { different scripts., } \\
\text { guided through } \\
\text { learning } \\
\text { stereotypes }\end{array}$ \\
\hline
\end{tabular}




\section{REFERENCES}

Bandura, A. (1986). Social foundations of thought and action.A social cognitive theory. Englewood Cliffs, NJ: Prentice- Hall.

Beal, C.R. (1994).Boys and girls: The development of gender roles. New York: McGraw- Hill.

Bem., S.( 1985). Androgyny and gender schema theory: A conceptual and empirical integration. In Theo B Sonderegger (Ed.), Nebraska Symposium on Motivation, 1984: Psychology and gender (pp, 179-226).Lincoln, NE: University of Nebraska Press.

Bussey, K., \& Bandura, A. (1984). Influence of gender and social power on sex linked modeling. Journal of Personality \& Social Psychology, 47, 1292-1302.

Ellis, H. (1894).Man and Women.London: Scott.

Idle, T., Wood, E. \&Desmarais,S.(1993). Gender role socialization in toy play situations: Mothers and fathers with their sons and daughters. Sex Roles, 28,679-691.

Kohlberg, L.( 1966). A cognitive-developmental analysis of children's sex role concepts and attitudes.In Eleanor.E.Maccoby (Ed), The development of sex differences (pp.52173).Stanford, CA: Stanford University Press.

Levy, G.D. \&Fivush, R. (1993). Scripts and gender: A new approach for examining gender role development.Developmental Review, 13,126-146.

Martin., C.L. \& Halverson, C.F.(1981). A schematic processing model of sex-typing and stereotyping in children.Child Development, 52, 1119-1134.

Mischel, W. (1993).Introduction to personality ( $5^{\text {th }}$ ed.)Forth Worth: Harcourt Brace Jovanovich.

Unger, R.K.(1990). Imperfect reflections on reality: Psychology constructs gender. In R.T. Hare Mustin\&J.Marecek (Eds.), Making a difference: Psychology and the construnction of gender (pp.102-149).New Haven, CT: Yale University Press. 